\title{
Borehole Integrity of Austenitized and Annealed Pipe Steels Suitable for Carbon Capture and Storage (CCS)
}

\author{
Anja Pfennig and Axel Kranzmann
}

\begin{abstract}
Properties of pipe steels for CCS (carbon capture and storage) technology require resistance against the corrosive environment of a potential CCS-site (heat, pressure, salinity of the aquifer, $\mathrm{CO}_{2}$-partial pressure). The influence of austenitzing in heat treatment routines of two different injection pipe steels (1.4034, X46Cr13 and 1.4021, X20Cr13) was evaluated. Steel coupons were austenitized at different temperatures (900$\left.1050{ }^{\circ} \mathrm{C}\right)$ for different lengths of time $(30-90 \mathrm{~min})$ before quenching and annealing prior to long term corrosion experiments $\left(60^{\circ} \mathrm{C}, 100 \mathrm{bar}\right.$, artificial brine close to a CCS-site in the Northern German Basin, Germany). In general, fewer pits are found on $\mathrm{X} 46 \mathrm{Cr} 13$. Comparing steels with $13 \%$ chromium each the higher carbon content of $\mathrm{X} 46 \mathrm{Cr} 13(0.46 \% \mathrm{C})$ results in a lower number of pits compared to $\mathrm{X20Cr13}(0.20 \% \mathrm{C})$. It is found that neither the carbon content of the steels nor austenitizing temperature has much influence, but local corrosion behaviour is most susceptible towards austenitzing time.
\end{abstract}

Index Terms-Corrosion, CCS, carbon storage, aquifer, austenitizing.

\section{INTRODUCTION}

Engineering a geological on-shore saline aquifer CCS-site (CCS Carbon Capture and Storage [1]-[3]) corrosion of injection pipe steels may become an issue when emission gasses, e.g. from combustion processes of power plants, are compressed into deep geological layers [4]-[12]. $\mathrm{CO}_{2}$-corrosion is sensitively dependent on alloy composition, contamination of alloy and media, environmental conditions like temperature, $\mathrm{CO}_{2}$ partial pressure, flow conditions and protective corrosion scales [6]-[8], [13]-[27]. Because the solubility of $\mathrm{FeCO}_{3}$ in water is low $\left(\mathrm{p}_{\mathrm{Ksp}}=10.54\right.$ at $25^{\circ} \mathrm{C}$ [28], [29] generally steels, that are exposed to $\mathrm{CO}_{2}$-environment, precipitate slow growing surface layers mainly comprised of $\mathrm{FeCO}_{3}$ (siderite) [4], [8], [30], which is also found in pits of locally corroded samples [21], [23]:

$$
\begin{aligned}
& \mathrm{CO}_{2}(\mathrm{~g})+\mathrm{H}_{2} \mathrm{O}(\mathrm{l}) \rightarrow \mathrm{H}++\mathrm{HCO}_{3}{ }^{-}(\mathrm{aq}) \\
& \text { cathodic: } 2 \mathrm{HCO}_{3^{-}}+2 \mathrm{e}^{-} \rightarrow 2 \mathrm{CO}_{3}{ }^{2-}+\mathrm{H}_{2} \\
& \text { anodic: } \begin{aligned}
\mathrm{Fe} & \rightarrow \mathrm{Fe}^{2+}+2 \mathrm{e}^{-} \\
\mathrm{Fe}^{2+}+\mathrm{CO}_{3}{ }^{2-} & \rightarrow \mathrm{FeCO}_{3}
\end{aligned}
\end{aligned}
$$

Manuscript received December 9, 2015; revised June 5, 2016. This work was supported in part by the U.S. Department of Commerce under Grant BS123456.

Anja Pfennig is with HTW University of Applied Sciences Berlin, Wilhelminenhofstraße 75 A, Gebäude C, 12459 Berlin (e-mail: anja.pfennig@htw-berlin.de).

Axel Kranzmann is with BAM Federal Institute of Materials Research and Testing, Unter den Eichen 87, 12205 Berlin (e-mail: axel.kranzmann@bam.de).

$$
\begin{gathered}
\mathrm{Fe}^{2+}+2 \mathrm{HCO}_{3}^{-} \rightarrow \mathrm{Fe}\left(\mathrm{HCO}_{3}\right)_{2} \\
\mathrm{Fe}\left(\mathrm{HCO}_{3}\right)_{2} \rightarrow \mathrm{FeCO}_{3}+\mathrm{CO}_{2}+\mathrm{H}_{2} \mathrm{O}
\end{gathered}
$$

Possibly the initial formation of $\mathrm{Fe}(\mathrm{OH})_{2}$ [7], [30] leads to an increase of the local $\mathrm{pH}$ near the hydroxide film resulting in the precipitation of an internal and external ferrous carbonate film, Han et al. [29]. Localized corrosion may then start especially at grain boundaries when the ferrous hydroxide film is locally damaged. The ferrous carbonate film is exposed to the brine, dissolves and is locally depassivated. As a consequence the carbonate film detaches (Fig. 1).

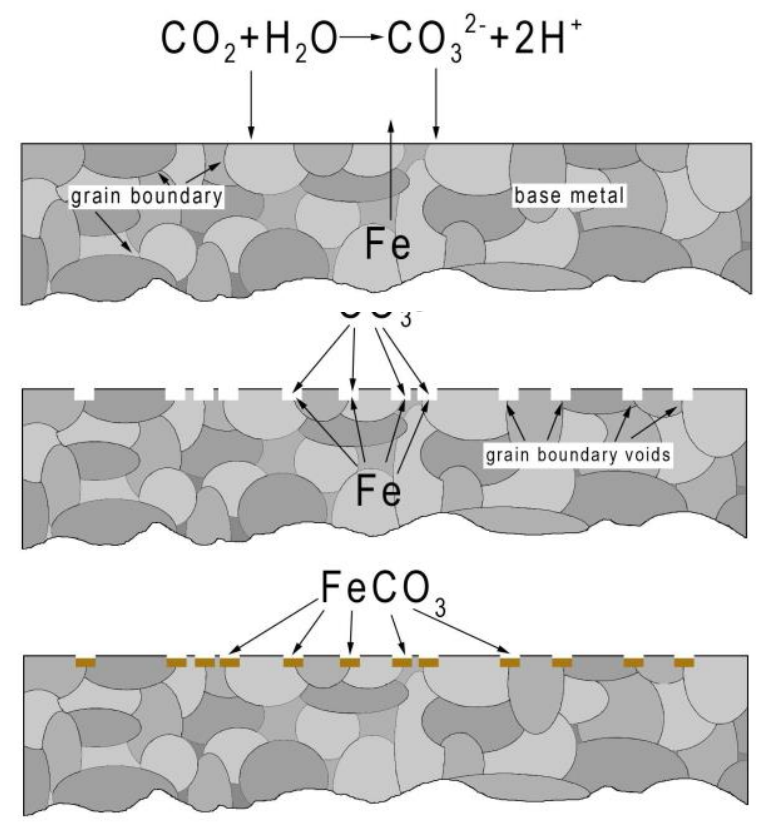

Fig. 1. Pit precipitation on steels initiated at grain boundaries (schematic).

The influence of heat treatment, that is: temperature and time of austenitisizing, cooling rate as well as temperature and time of annealing, has been shown by various authors. The presence and amount of retained austenite as a microstructural component resulting from the heat treatments applied has a beneficial effect on the pitting corrosion resistance of 13\%-chromium steels (13CrNiMo) [31]. A higher $\mathrm{Ni}$ and $\mathrm{Cr}$ content in the heat treated steels improve the corrosion resistance [31], [32]. Hou et al. introduce a method of empirically calculating the influence of alloying elements in heat treated steels [33]. Cvijović and G. Radenković showed that the corrosion resistance of duplex steels with chromium contents even as high as $22-27 \%$ varied with solidification mode and annealing condition [34]. In general raising the annealing temperature lowers the pitting potential of lean duplex stainless steels [34]-[36]. The lowest potentials, corresponding to the transition from metastable to stable 
pitting, are observed for annealing at $900{ }^{\circ} \mathrm{C}$ while a maximum improvement of corrosion stability can be achieved by annealing at $1200{ }^{\circ} \mathrm{C}$ [34]. The better corrosion resistance of martensitic stainless steels with $13 \% \mathrm{Cr}$ at higher austenitizing temperature $\left(980-1050{ }^{\circ} \mathrm{C}\right)$ is related to the dissolution of carbides [36]-[38]. The precipitation of Cr-rich $\mathrm{M}_{23} \mathrm{C}_{6}$ and $\mathrm{M}_{7} \mathrm{C}_{12}$ carbides reduced the resistance of passive film and pitting corrosion [36] and has high impact on mechanical properties due to secondary hardening [37]. The influence of heat treatment on the microstructure and mechanical properties is well known [36], [39], [40]. However for C-Mn (carbon) steels in a $\mathrm{H}_{2} \mathrm{~S}$-containing $\mathrm{NaCl}$ solution the martensitic microstructure has the highest corrosion rate up to two orders of magnitude higher than ferritic or ferritic-bainitic microstructures due to the fact that martensitic grain boundaries are more reactive [41].

\section{EXPERIMENTAL PROCEDURE}

The steel qualities for laboratory experiments X20Cr13 (1.4021, AISI $420 \mathrm{~J}$ ) and X46Cr13 (1.4034, AISI $420 \mathrm{C})$ are used as injection pipe. Exposure tests in $\mathrm{CO}_{2}$-saturated aquifer brine were carried out using samples made of thermally treated specimen of the steels with $8 \mathrm{~mm}$ thickness, $20 \mathrm{~mm}$ width, $50 \mathrm{~mm}$ length. Austenitizing prior to exposure was done at $950{ }^{\circ} \mathrm{C}, 1000{ }^{\circ} \mathrm{C}$ and $1050{ }^{\circ} \mathrm{C}$ for $30 \mathrm{~min}, 60 \mathrm{~min}$ and $90 \mathrm{~min}$. Following usual heat treatment protocols the specimen were then annealed at $650{ }^{\circ} \mathrm{C}$ for $30 \mathrm{~min}$ to gain martensitic microstructure with sufficient hardness and toughness. A hole of $3.9 \mathrm{~mm}$ diameter was used for sample positioning. Samples of each base metal were positioned within the vapour phase and within the liquid phase. The brine (as known to be similar to the Stuttgart Aquifer [42]: $\mathrm{Ca}^{2+}$ : $1760 \mathrm{mg} / \mathrm{L}, \mathrm{K}^{2+}: 430 \mathrm{mg} / \mathrm{L}_{,} \mathrm{Mg}^{2+}: 1270 \mathrm{mg} / \mathrm{L}, \mathrm{Na}^{2+}: 90,100$ $\mathrm{mg} / \mathrm{L}, \mathrm{Cl}^{-}: 143,300 \mathrm{mg} / \mathrm{L}, \mathrm{SO}_{4}{ }^{2-}: 3600 \mathrm{mg} / \mathrm{L}, \mathrm{HCO}_{3}{ }^{-}: 40 \mathrm{mg} / \mathrm{L}$ ) was synthesized in a strictly orderly way to avoid precipitation of salts and carbonates. Flow control ( $3 \mathrm{NL} / \mathrm{h})$ of the technical $\mathrm{CO}_{2}$ (purity 99,995 vol.-\%)) into the brine at ambient pressure was done by a capillary meter GDX600_man by QCAL Messtechnik GmbH, Munic. The exposure of the samples between $700 \mathrm{~h}$ to $4000 \mathrm{~h}$ was disposed in reaction vessels according to the conditions at the geological site at $60{ }^{\circ} \mathrm{C}$ at ambient pressure - each material in a separated reaction vessel [21] (Fig. 2).

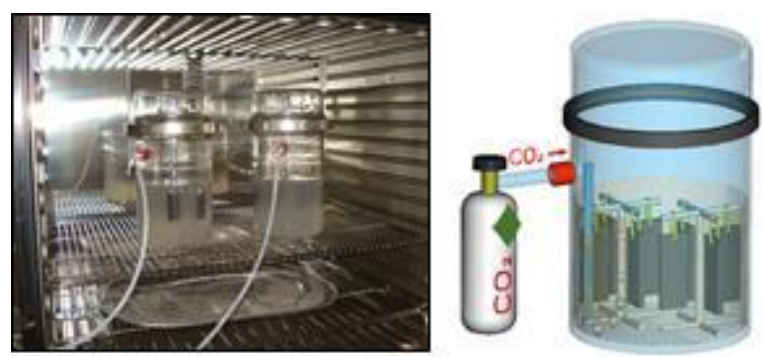

Fig. 2. Reaction vessels and experimental set up.

Before corrosion tests the surfaces of the steels were activated by grinding with SiC-Paper down to $120 \mu \mathrm{m}$ under water. After the corrosion tests, the samples were cut partly for scale analysis with the corrosion layer and prepared partly for kinetic analysis after the scale was etched. Descaling of the samples was performed by exposure to $37 \% \mathrm{HCl}$. Then parts of the samples were embedded in a cold resin (Epoxicure, Buehler), cut and polished first with SiC-Paper from $180 \mu \mathrm{m}$ to $1200 \mu \mathrm{m}$ under water and then finished with diamond paste $6 \mu \mathrm{m}$ and $1 \mu \mathrm{m}$.

Different light optical and electron microscopy techniques were performed on specimens to investigate the layer structures and morphology of the samples. X-ray diffraction was carried out in a URD-6 (Seifert-FPM) with CoK $\alpha$-radiation with an automatic slit adjustment, step $0.03^{\circ}$ and count $5 \mathrm{sec}$. Phase analysis was performed by matching peak positions automatically with PDF-2 (2005) powder patterns. Mainly structures that were likely to precipitate from the steels were chosen of the ICSD and refined to fit the raw-data-files using POWDERCELL 2.4 [43] and AUTOQUAN $®$ by Seifert FPM. To characterise the pitting corrosion, 3-D-images were realized by the double optical system Microprof TTV by FRT. Kinetics of the corrosion were determined by the corrosion rates which were calculated via mass change of the samples before and after corrosion testing according to DIN 50905 part 1-4 and using the semi-automatic analyzing program Analysis Docu ax-4 by Aquinto.

\section{RESULTS AND DISCUSSION}

The inhomogeneous corrosion layer specimen surfaces after $700 \mathrm{~h}, 2000 \mathrm{~h}$ and $4000 \mathrm{~h}$ of exposure to $\mathrm{CO}_{2}$-saturated saline aquifer water on consists of either a non-consistent carbonate layer or carbon precipitates covering pits precipitated on the samples surface. X46Cr13 and X20Cr13 steels are known for susceptibility towards local corrosion. Therefore pitting will be taken into account more closelyeven if thin surface corrosion layers occurred after long exposure times (Fig. 3).



Fig. 3. Sample surfaces after $700 \mathrm{~h}$ of exposure.

As a measure of quality the hardness was analyzed prior to exposure. Longer austenitzing times lead to lower hardness and higher austeniztizing temperatures result in lower hardness due to grain growth processes at longer austenization time at higher temperatures. Larger grains within the microstructure result in longer dislocation paths allowing for plastic deformation. In general the hardness of $\mathrm{X} 46 \mathrm{Cr} 13$ was higher by a factor of 2 compared to X20Cr13 due to the higher $\mathrm{C}$-content and accompanying carbide precipitation. Reason is the precipitation of iron and chromium carbides that act as dislocation barriers reducing 
plastic deformation.

To evaluate the influence of the heat treatment on the surface and local corrosion behavior the samples were examined via light optical methods to predict the number of pits and pit depths. Kinetics was obtained via weight loss according to DIN 50905 after exposure to the $\mathrm{CO}_{2}$-saturated aquifer water. Fig. 4 demonstrates that the surface corrosion behavior of $\mathrm{X} 46 \mathrm{Cr} 13$ and $\mathrm{X} 20 \mathrm{Cr} 13$ is comparable after long exposure times. Here the results of all heat treatment parameters have been combined to evaluate the influence of the carbon content. Even if $\mathrm{X} 46 \mathrm{Cr} 13$ has a slightly higher corrosion rate after only $700 \mathrm{~h}$ of exposure the corrosion rate of both steel qualities is approximately $0.01 \mathrm{~mm} /$ year after $4000 \mathrm{~h}$ of exposure.

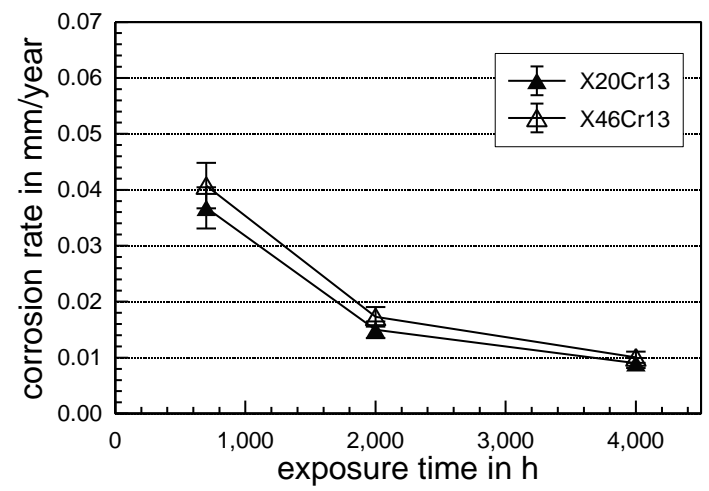

Fig. 4. Combined surface corrosion rates of X46Cr13 and $\mathrm{X} 20 \mathrm{Cr} 13$ without regard to austenitizing.

Similar results are obtained when focusing on the austenitizing temperature; after $4000 \mathrm{~h}$ of exposure. The corrosion rate is about $0.01 \mathrm{~mm} /$ year no regard to the temperatures $950{ }^{\circ} \mathrm{C}, 1000{ }^{\circ} \mathrm{C}$ or $1050{ }^{\circ} \mathrm{C}$ (Fig. 5).

The influence of exposure time is more significant as demonstrated in Fig. 6. Austenitizing for only $30 \mathrm{~min}$ at either one of the three different austenitizing temperatures gives lowest corrosion rates after short exposure times of X20Cr13 and $\mathrm{X} 46 \mathrm{Cr} 13(700 \mathrm{~h})$ to $\mathrm{CO}_{2}$-saturated saline aquifer and after long exposure times $(4000 \mathrm{~h})$. The corrosion rate is approximately $0.005 \mathrm{~mm} /$ year and therefore lower by a factor of 2 .



Fig. 5. Surface corrosion rate of $\mathrm{X} 46 \mathrm{Cr} 13$ and $\mathrm{X} 20 \mathrm{Cr} 13$ combined as a function of austenitizing temperature after $4000 \mathrm{~h}$ of exposure to CCS environment.

In general, the corrosion resistance increases with shorter austenitizing time and lower austenizing temperature. The austenizing time has the greatest influence on the surface corrosion rate (Fig. 6), which scales with the elongation of austenitizing, but is neglectable when evaluating local corrosion phenomena [44]. Specimens heated to $950{ }^{\circ} \mathrm{C}$ and annealed for 30 minutes exhibit the lowest corrosion rates. The highest corrosion rate is found for $\mathrm{X} 20 \mathrm{Cr} 13$ austenitized at $1050{ }^{\circ} \mathrm{C}$ for 60 minutes. After $700 \mathrm{~h}$ the corrosion rates have the highest values, but as time proceeds the rates decrease.

Comparing local corrosion of X20Cr13 and X46Cr13 Fig. 7 shows that $\mathrm{X} 20 \mathrm{Cr} 13$ shows a better pit corrosion resistance. $\mathrm{X} 20 \mathrm{Cr} 13$ exhibits an average of 3508814 pits per $\mathrm{m}^{2}$, whereas the $\mathrm{X} 46 \mathrm{Cr} 13$ averages 9622 pits per $\mathrm{m}^{2}$ after $700 \mathrm{~h}$ of exposure. Here for both steel qualities austenitizing at $1000{ }^{\circ} \mathrm{C}$ seems to give better results as austenitzing at $950{ }^{\circ} \mathrm{C}$ or $1050{ }^{\circ} \mathrm{C}$.

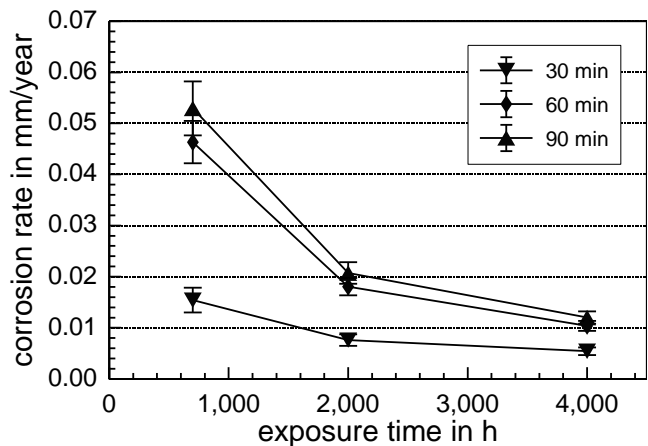

Fig. 6. Surface corrosion rate of $\mathrm{X} 46 \mathrm{Cr} 13$ and $\mathrm{X} 20 \mathrm{Cr} 13$ combined as a function of austenitizing time after $4000 \mathrm{~h}$ of exposure to CCS environment

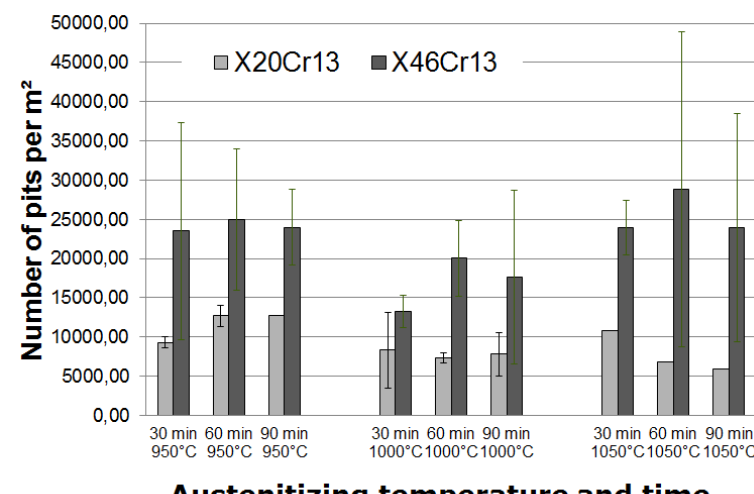

Fig. 7. Number of pits on $\mathrm{X} 20 \mathrm{Cr} 13$ and $\mathrm{X} 46 \mathrm{Cr} 13$ after applying different austenitizing routines and annealing at $650{ }^{\circ} \mathrm{C}$ for $30 \mathrm{~min}$. prior to exposure

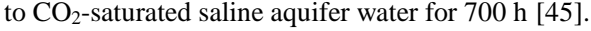

In the beginning the corrosion rates are significantly higher at higher austenitizing temperatures and longer austenitizing times, but after $4000 \mathrm{~h}$ the corrosion rates are of not much difference. Most likely the corse grain structure is corrosively attacked at the grain boundaries, but once a sufficient corrosion layer has precipitated the mutual diffusion of ionic species towards the metal surface and into the surface is significantly slowed down with inceasing thickness of the corrosion layer. In addition the grain growth process is limited at shorter austenitizing temperature giving the equilibration as little time as possible with additionally short austenitizing time. If grain growth is slow the small grain sizes within the microstructure will result in lower corrosion rates.

X20Cr13 also shows a better local corrosion resistance compared to $\mathrm{X} 46 \mathrm{Cr} 13$ when taking into account pit diameters. 
The average pit on $\mathrm{X} 46 \mathrm{Cr} 13$ (diameter average $=249 \mu \mathrm{m}$ ) is 5 times larger as the average pit on the X20Cr13 $(49 \mu \mathrm{m})$ [46]. Most pits on both steel qualities have a diameter of $51 \mu \mathrm{m}$ to $100 \mu \mathrm{m}$ after $700 \mathrm{~h}$ of exposure - with the number of pits of $\mathrm{X} 46 \mathrm{Cr} 13$ higher than $\mathrm{X} 20 \mathrm{Cr} 13$ by a factor of 3 (Fig. 8).

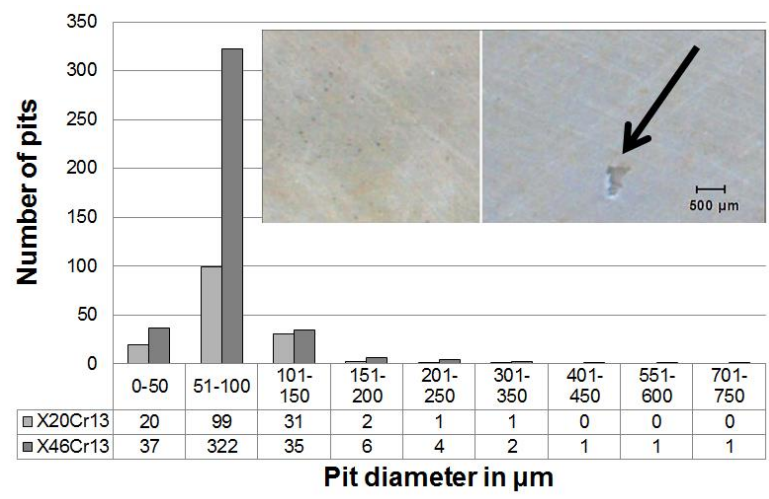

Fig. 8. Number of pits precipitated on $\mathrm{X} 20 \mathrm{Cr} 13$ and $\mathrm{X} 46 \mathrm{Cr} 13$ divided in diameter groups after applying different austenitizing routines and annealing at $650{ }^{\circ} \mathrm{C}$ for $30 \mathrm{~min}$. prior to exposure to $\mathrm{CO}_{2}$-saturated saline aquifer water for $700 \mathrm{~h}$.

Even if the maximum pit diameter of pits precipitated on $\mathrm{X} 46 \mathrm{Cr} 13$ succeed those precipitated on $\mathrm{X} 20 \mathrm{Cr} 13$ by a factor of 3.5 (Fig. 9) for steel coupons austenitized at $950{ }^{\circ} \mathrm{C}$ for 90 minutes the average pit diameter of both steel qualities does not differ significantly. Furthermore there is no significant influence on the austenitizing routines prior to exposure to CCS environment. The average pit diameter does not succeed $100 \mu \mathrm{m}$ after $700 \mathrm{~h}$ of exposure. Notice, critical parameter to assess the influence of pit precipitation is preferably not the diameter, but depth of pits. But, after $700 \mathrm{~h}$ to $4000 \mathrm{~h}$ the depth of pits were shown to be quite comparable and these will be evaluated more closely in future.

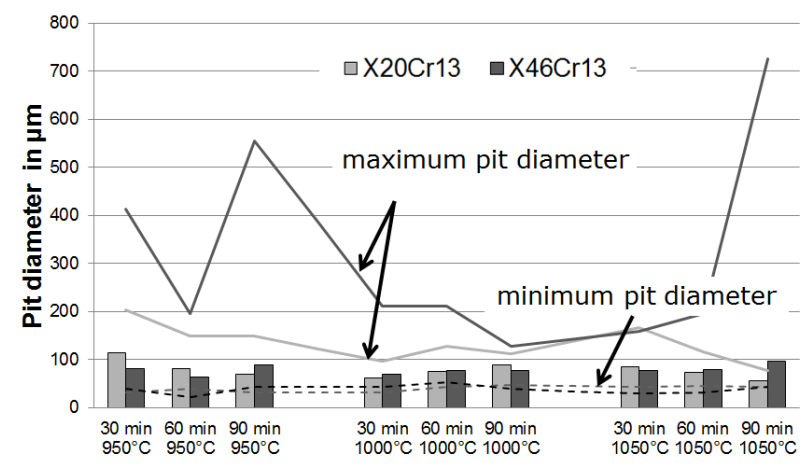

\section{Austenitizing temperature and time}

Fig. 9. Diameter of pits precipitated on $\mathrm{X} 20 \mathrm{Cr} 13$ and $\mathrm{X} 46 \mathrm{Cr} 13$ after applying different austenitizing routines and annealing at $650{ }^{\circ} \mathrm{C}$ for $30 \mathrm{~min}$. prior to exposure to $\mathrm{CO}_{2}$-saturated saline aquifer water for $700 \mathrm{~h}$.

Fig. 10 shows results from combined DoE-Analysis performed after Klein [45], [46] with respect to alloy composition and carbon content, austenitizing time and austenitizing temperature. This method does not allow for the evaluation of dependent parameters such as the combination of both, carbon content and autenitzing time. Still, the results prove that the corrosion resistance regarding surface corrosion is only dependent on the austenitizing time, but neither the austenitizing temperature nor the carbon content of the base material [23].

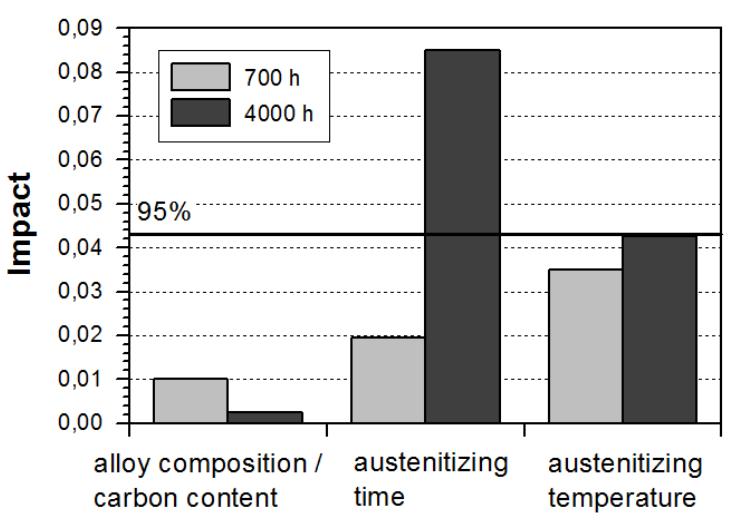

Fig. 10. The impact of the experimental parameters on the surface corrosion rate after $700 \mathrm{~h}$ and $4000 \mathrm{~h}$ of exposure time with $95 \%$-confidence interval.

The fact that the carbon content exhibits the biggest impact on the local corrosion behaviour is shown in the results of the DoE analysis revealed by Fig. 11. But, since none of the parameters are within the liability regime the results here prove a tendency but do not show significant dependence of carbon content on the local corrosion behavior [45].

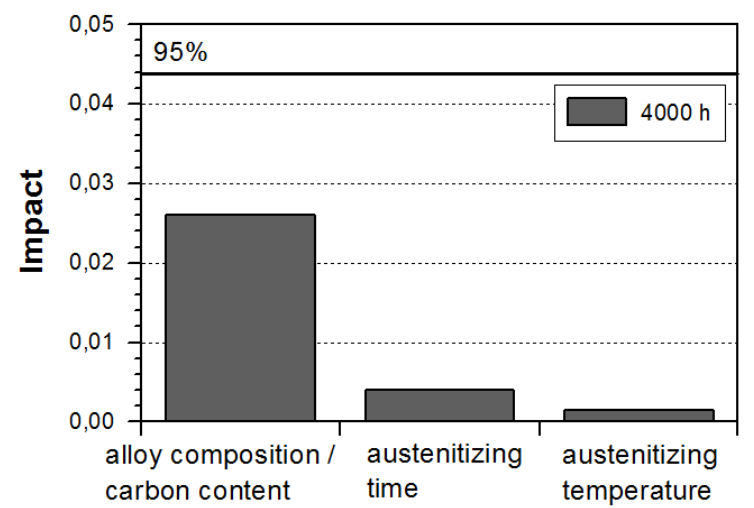

Fig. 11. Impact of the experimental parameters on the local corrosion behaviour of $\mathrm{X} 20 \mathrm{Cr} 13$ and $\mathrm{X} 46 \mathrm{Cr} 13$ after $4000 \mathrm{~h}$ of exposure time with $95 \%$-confidence interval.

The austenitizing time is the only parameter during heat treatmeant procedure that shows significant influence on surface corrosion behavior of 13\%-chromium steels. Local corrosion behavior is not influenced by either austenitizing time or temperature or alloy composion. Most likely pit precipitation is a phenomenon of local elemental decomposition, depleting the alloy matrix of chromium leading to localized degradation and pit growth. Still, in order to prefent severe corrosion during CCS steels should be austenitized as short as possible and pit depth shoud always been taken into account, even if pit diameters remain small after long exposure times.

\section{CONCLUSION}

When engineering a CCS-site $\mathrm{CO}_{2}$ is injected into deep geological layer supposedly in its liquid or supercritical phase. As a worst case scenario during carbon capture and storage is that intermissions of $\mathrm{CO}_{2}$ injection may lead to a rising the water level within the injection pipe. As a consequence of this three-phase boundary (liquid brine, supercritical or gaseous $\mathrm{CO}_{2}$ and solid injection pipe steel) corrosion products precipitate and pits are formed. In general, the shorter 
austenitizing times and lower austenitizing temperatures of the steel qualities prior to exposure to CCS environment exhibit the lowest corrosion rates. Still, the austenitizing time has no significant impact on the number of pit and pit sizes. The following facts could be summarized acting as an aid to heat treatment of steels used in CCS-technology. Most important finding are:

1) Shorter austenitizing time at lower austenitizing temperature results in better corrosion resistance regarding surface corrosion. Especially the austenitizing time has a significant impact.

2) A higher carbon content of the steels (X20Cr13 < $\mathrm{X} 46 \mathrm{Cr} 13$ ) increases the number of pits.

3) After $4000 \mathrm{~h}$ of exposure there is no difference in surface corrosion rates comparing $\mathrm{X} 20 \mathrm{Cr} 13$ and $\mathrm{X} 46 \mathrm{Cr} 13$

4) The alloy composition as well as the austenitizing procedure has no impact on pit diameters.

\section{ACKNOWLEDGMENT}

This work was supported by the FNK (Fachkonferenz für wissenschaftliche Nachwuchskräfte) of the Applied University of Berlin, HTW and by IMPACT (EU-Project EFRE 20072013 2/21).

\section{REFERENCES}

[1] D. C. Thomas, "Carbon dioxide capture for storage in deep geologic formations - results from $\mathrm{CO}_{2}$ capture project," Capture and Separation of Carbon Dioxide form Combustion Sources, Elsevier Ltd UK, 2005.

[2] M. van den Broek, R. Hoefnagels, E. Rubin, W. Turkenburg, and A. Faaij, "Effects of technological learning on future cost and performance of power plants with $\mathrm{CO}_{2}$ capture," Projects Costs of Generating Electricity, Progress in Energy and Combustion Science, pp. 177-187, 2010.

[3] GeoForschungszentrum Potsdam, $\mathrm{CO}_{2}$-SINK - drilling project, description of the project PART 1, pp. 1-39, 2006.

[4] S. Nešić, "Key issues related to modelling of internal corrosion of oil and gas pipelines - A review," Corrosion Science, vol. 49, pp. 4308-4338, 2007

[5] S. Hurter, "Impact of mutual solubility of $\mathrm{H}_{2} \mathrm{O}$ and $\mathrm{CO}_{2}$ on injection operations for geological storage of $\mathrm{CO}_{2}$," in Proc. International Conference of the Properties of Water and Steem, Berlin, September 8-11.

[6] L. Zhang, J. Yang, J. S. Sun, and M. Lu, "Effect of pressure on wet $\mathrm{H}_{2} \mathrm{~S} / \mathrm{CO}_{2}$ corrosion of pipeline steel," in Proc. NACE Corrosion Conference and Expo, New Orleans, Louisiana, USA, March 16th-20th, 2008.

[7] L. J. Mu and W. Z. Zhao, "Investigation on carbon dioxide corrosion behaviors of $13 \mathrm{Cr}$ stainless steel in simulated strum water," Corrosion Science, pp. 1-24, 2009.

[8] M. Bonis, "Weight loss corrosion with $\mathrm{H}_{2} \mathrm{~S}$ : From facts to leading parameters and mechanisms," in Proc. NACE Corrosion Conference and Expo, New Orleans, Louisiana, USA, March 16th-20th, 2008.

[9] IPCC. (2005). IPCC carbon dioxide capture and storage: Technical summary. Geological Storage. [Online]. Available: http://www.greenfacts.org/en/co2-capture-storage/figtableboxes/figur e-7.htm

[10] M. Seiersten, "Material selection for separation, transportation and disposal of $\mathrm{CO}_{2}$," NACE Corrosion, 2001.

[11] Z. D. Cui, S. L. Wu, S. L. Zhu, and X. J. Yang, "Study on corrosion properties of pipelines in simulated produced water saturated with supercritical $\mathrm{CO}_{2}$," Applied Surface Science, vol. 252, pp. 2368-2374, 2006.

[12] A. Pfennig and A. Kranzmann, "Reliability of pipe steels with different amounts of $\mathrm{C}$ and $\mathrm{Cr}$ during onshore carbon dioxide injection," International Journal of Greenhouse Gas Control, vol. 5, pp. 757-769, 2011.

[13] J. Enerhaug, "A study of localized corrosion in super martensitic stainless steel weldments," thesis, Norwegen University of Science and Technology (NTNU), Trondheim, 2002.
[14] V. Neubert, Beanspruchung der Förderrohrtour durch korrosive Gase, VDI-Berichte Nr. 2026, 2008.

[15] R. Kirchheiner and P. Wölpert, Qualifizierung metallischer Hochleistungs-werkstoffe für die Energieumwandlung in geothermischen Prozessen, VDI-Berichte Nr. 2026, 2008

[16] H. Zhang, Y. L Zhao, and Z. D. Jiang, "Effects of temperature on the corrosion behaviour of $13 \mathrm{Cr}$ martensitic stainless steel during exposure to $\mathrm{CO}_{2}$ and Cl- environment," Material Letters, vol. 59, pp. 3370-3374, 2005 .

[17] J. N. Alhajji and M. R. Reda, "The effect of alloying elements on the electrochemical corrosion of low residual carbon steels instagnant $\mathrm{CO}_{2}$-saturated brine," Corrosion Science, vol. 34, no. 11, pp. 1899-1911, 1993.

[18] Y. S. Choi and S. Nešić, Corrosion behaviour of carbon steel in supercritical $\mathrm{CO}_{2}$-water environments," in Proc. NACE Corrosion Conference and Expo, New Orleans, Louisiana, USA, March 16th-20th, 2008.

[19] X. Jiang, S. Nešić, and F. Huet, "The effect of electrode size on electrochemical noise measurements and the role of chloride on localized $\mathrm{CO}_{2}$ corrosion of mild steel," in Proc. NACE Corrosion Conference and Expo, New Orleans, Louisiana, USA, March 16th 20th, 2008.

[20] Z. Ahmad, I. M. Allam, and B. J. Abdul Aleem, "Effect of environmental factors on the atmospheric corrosion of mild steel in aggressive sea coastal environment," Anti Corrosion Methods and Materials, vol. 47, pp. 215-225, 2000.

[21] A. Pfennig and R. Bäßler, "Effect of $\mathrm{CO}_{2}$ on the stability of steels with $1 \%$ and $13 \% \mathrm{Cr}$ in saline water," Corrosion Science, vol. 51, issue 4, pp. 931-940, 2009.

[22] A. Pfennig and A. Kranzmann, "The role of pit corrosion in engineering the carbon storage site Ketzin, Germany," WIT Transactions on Ecology and the Environment, vol. 126, pp. 109-118, 2010.

[23] A. Pfennig, P. Zastrow, and A. Kranzmann, "Influence of heat treatment on the corrosion behaviour of stainless steels during $\mathrm{CO}_{2}$-sequestration into saline aquifer," International Journal of Green House Gas Control, vol. 15, pp. 213-224, 2013.

[24] R. Nyborg, "Controlling internal corrosion in oil and gas pipelines, business briefing: exploration \& production: The oil \& gas review," issue 2, pp. 70-74, 2005.

[25] D. S. Carvalho, C. J. B. Joia, and O. R. Mattos, "Corrosion rate of iron and iron-chromium alloys in $\mathrm{CO}_{2}$-medium," Corrosion Science, vol. 47, pp. 2974-2986, 2005.

[26] B. R. Linter and G. T Burstein, "Reactions of pipeline steels in carbon dioxide solutions," Corrosion Science, vol. 41, pp. 117-139, 1999.

[27] S. L Wu, Z. D. Cui, G. X. Zhao, M. L. Yan, S. L. Zhu, and X. J. Yang, "EIS study of the surface film on the surface of carbon steel form supercritical carbon dioxide corrosion," Applied Surface Science, vol 228, pp. 17-25, 2004.

[28] B. Brown, S. R. Parakala, and S. Nešić, " $\mathrm{CO}_{2}$ corrosion in the presence of trace amounts of $\mathrm{H}_{2} \mathrm{~S}$," Corrosion, 04736, pp. 1-28, 2004

[29] J. Han, Y. Yang, S. Nešić, and B. N. Brown, "Roles of passivation and galvanic effects in localized $\mathrm{CO} 2$ corrosion of mild steel," in Proc. NACE Corrosion Conference and Expo, New Orleans, Louisiana, USA, March 16th - 20th, 2008, p. 08332.

[30] A. Pfennig, H. Wolthusen, P. Zastrow, and A. Kranzmann, "Evaluation of heat treatment performance of potential pipe steels in CCS-environment," Carbon Dioxide Management and Other Technologies, vol. 1, pp. 15-22, 2015.

[31] J. Banaś, U. Lelek-Borkowska, B. Mazurkiewicz, and W. Solarski, "Effect of $\mathrm{CO}_{2}$ and $\mathrm{H}_{2} \mathrm{~S}$ on the composition and stability of passive film on iron alloy in geothermal water," Electrochimica Acta, vol. 52, pp. 5704-5714, 2007

[32] P. D. Bilmes, C. L. Llorente, C. M. Méndez, and C. A. Gervasi, "Microstructure, heat treatment and pitting corrosion of $13 \mathrm{CrNiMo}$ plate and weld metals," Corrosion Science, vol. 51, issue 4, pp 876-882, 2009.

[33] Ş. Bülbül and Y. Sun, "Corrosion behaviours of high Cr-Ni cast steels in the $\mathrm{HCl}$ solution," Journal of Alloys and Compounds, vol. 598, pp. 143-147, 2010.

[34] B. Hou, Y. Li, Y. Li, and J. Zhang, "Effect of alloy elements on the anti-corrosion properties of low alloy steel," Bull. Mater. Sci, vol. 23, no. 3, pp. 189-192, 2010.

[35] Z. Cvijović and G. Radenković, "Microstructure and pitting corrosion resistance of annealed duplex stainless stell," Corrosion Science, vol. 48, pp. 3887-3906, 2006.

[36] L. Zhang, W. Zhang, Y. Jiang, B. Deng, D. Sun, and J. Li, "Influence of annealing treatment on the corrosion resistance of lean duplex stainless 
steel 2101," Electrochimica Acta, vol. 54, no. 23, pp. 5387-5392, 2009.

[37] Y. S. Choi, J. G. Kim, Y. S. Park, and J. Y. Park, "Austenitzing treatment influence on the electrochemical corrosion behaviour of 0.3C-14Cr-3Mo martnesitic stainless steel," Materials Letters, vol. 61, pp. 244-247, 2007.

[38] A. N. Isfahany, H. Saghafian, and G. Borhani, "The effect of heat treatment on mechanical properties and corrosion behaviour of AISI420 martensitic stainless steel," Journal of Alloys and Compounds, vol. 509, pp. 3931-3936, 2011.

[39] J. Y. Park and Y. S. Park, "The effects of heat-treatment parameters on corrosion resistance and phase transformation of $14 \mathrm{Cr}-3 \mathrm{Mo}$ martensitic stainless steel," Materials Science and Engineering, vol. 449-451, pp. 1131-1134, 2007.

[40] D. Dyja, Z. Stradomski, and A. Pirek, "Microstructural and fracture analysis of aged cast duplex steel," Strength of Materials, vol. 40, no. 1 , pp. $122-125,2008$

[41] M. A. Lucio-Garciaa, J. G. Gonzalez-Rodrigueza, M. Casalesc, L. Martinezc, J. G. Chacon-Navaa, M. A. Neri-Floresa, and A. Martinez-Villafañea, "Effect of heat treatment on $\mathrm{H}_{2} \mathrm{~S}$ corrosion of a micro-alloyed C-Mn steel," Corrosion Science, vol. 51, pp. 2380-2386, 2009.

[42] A. Förster, B. Norden, and K. Zinck-Jørgensen et al., "Baseline characterization of the $\mathrm{CO}_{2}$ SINK geological storage site at Ketzin, Germany," Environmental Geosciences, vol. 13, no. 3 pp. 145-161, 2006.

[43] S. W. Kraus and G. Nolze, "POWDER CELL - a program for the representation and manipulation of crystal structures and calculation of the resulting X-ray powder patterns," J. Appl. Cryst. vol. 29, pp. 301-303, 1996

[44] J. Schiz, Einfluss der Austenitisierungsparameter auf die Korrosionsbeständigkeit von Stählen in CCS-Umgebung, Bachelor-Thesis zur Erlangung des Grades B.Sc. im Fachbereich Maschinenbau an der HTW Berlin, 2011.
[45] A. Pfennig, J. Schiz, Johann, and A. Kranzmann, "The role of austenitizing routines of pipe steels during CCS," TMS 2015 Energy Technology 2015, Carbon Dioxide Management and Other Technologies, vol. 1, pp. 131-138, 2015.

[46] B. Klein, Versuchsplanung DoE. Kassel: Oldenbourg Verlag. 3-486-27387-6, 2004.

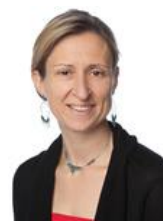

A. Pfennig was born in Bad Bibra, Germany in 1956. She studied minerology at the Rheinische Friedrich Wilhelms Universtiy Bonn, Germany, where she graduated in 1997. Her Ph.D. in ceramic moulds for liquid metal casting was earned in 2001 from the Friedrich Alexander University of Erlangen, Germany. She then worked for Siemens Energy in charge of ceramic shields and transferred to Berlin in 2008 where she currently teaches material science for engineering students at the Applied University Berlin, HTW. A. Pfennig's research interest and expertise is in the field of corrosion fatigue of materials at high temperature and high pressure simulating geothermal environments.



A. Kranzmann was born in Büdelsdorf, Germany in April 1970. He studied Physics at the University of Cologne, Germany and finished his Ph.D. 1988 in metallurgy at the MPI for Metals Research, Germany, where he worked from 1986-1991. He then transferred to ABB AG in Heidelberg as head of section in charge of materials- and surface technology and later R\&D coordination manager of ABB Germany until 2001. From then on and currently he is group leader "microstructure of materials" at the BAM, Federal Institute for Research and Development. A. Kranzmann's research interest and expertise is in the field of high temperature and gas corrosion, ageing of metals, experimental simulation of high-temperature processes and research of surface topology. 